Historic, Archive Document

Do not assume content reflects current scientific knowledge, policies, or practices. 
fin:

,

(x)

i.

$1,0^{14}$

I!ray

4

ir.

Irit

|lin:

(itin

a. 


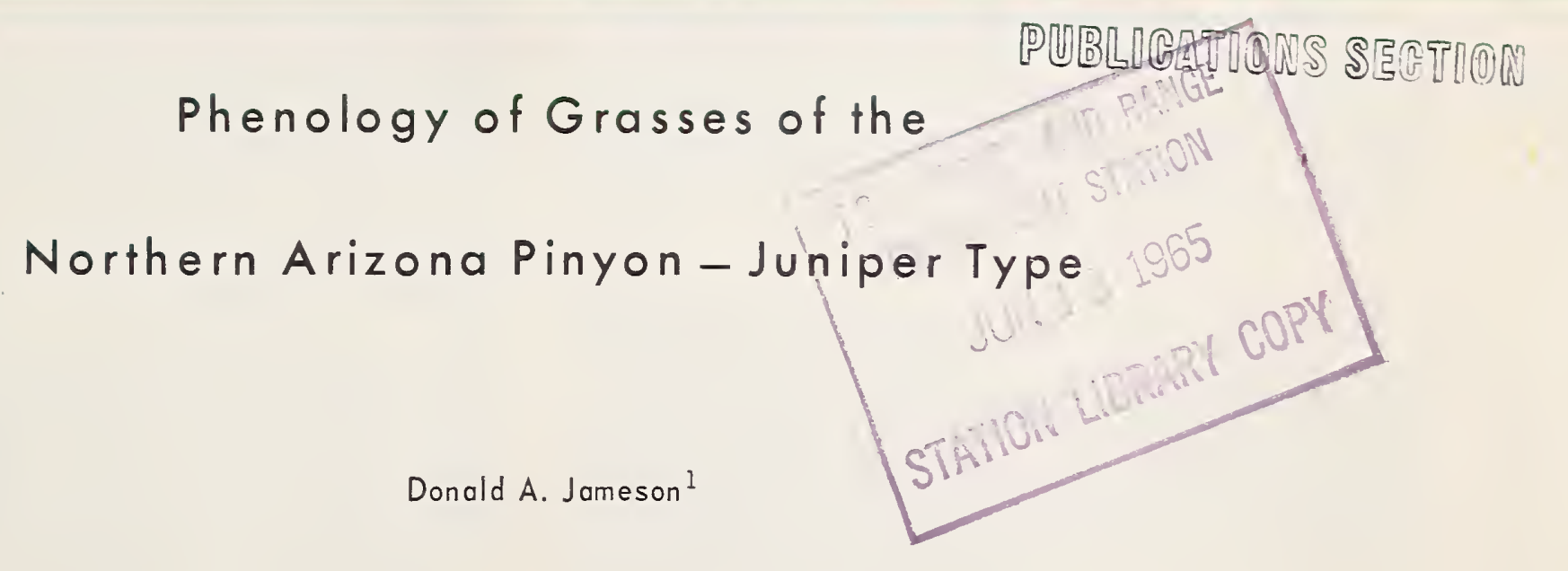

Phenology of forage plants can be used to predict time of range readiness, to predict amount of forage growth, as a guide to forage quality, and as an aid in designing grazing systems. To provide this information for the pinyon-juniper type in northern Arizona (fig. 1 ), height and stages of development of several important native grasses were recorded from 1957 to 1960 . The five study areas, located 20 to 40 miles north, south, and west of Flagstaff, range in elevation from 5,800 to 6,500 feet, and average annual precipitation from 11 to 20 inches.

\section{TIME OF GRASS GROWTH}

In northern Arizona, two nearly distinct growing seasons occur during or following two

lPrincipal Plant Physiologist, located at Elagstaff, in cooperation with Arizona State College; central headquarters maintained at Fort Colzins, in cooperation with colorado State University. rainfall periods (fig. 2). One growth period is characterized by cool-season grasses; the other, by warm-season grasses, (table 1, fig. 3). During the spring growing season, which includes the period from about April 1 to about June 15, cool-season grasses are seasonally dominant. These include mutton bluegrass, prairie Junegrass, bottlebrush squirreltail, and western wheatgrass. These grasses utilize winter and spring precipitation. The summer growing season, which begins about the first week of July and ends

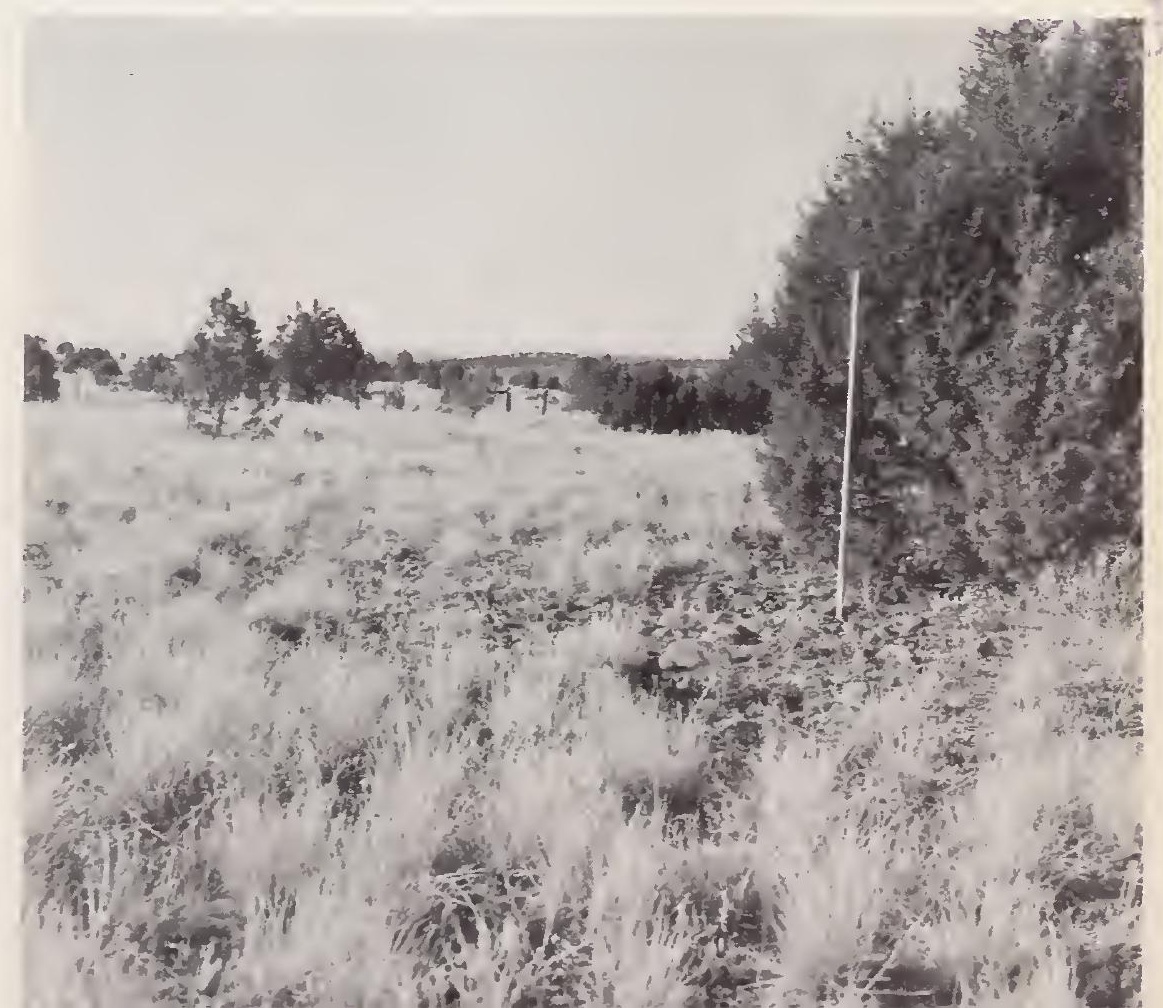

Figure 1.--The study area in the pinyon-juniper type, 10 miles east of Ashfork, Amizona. 


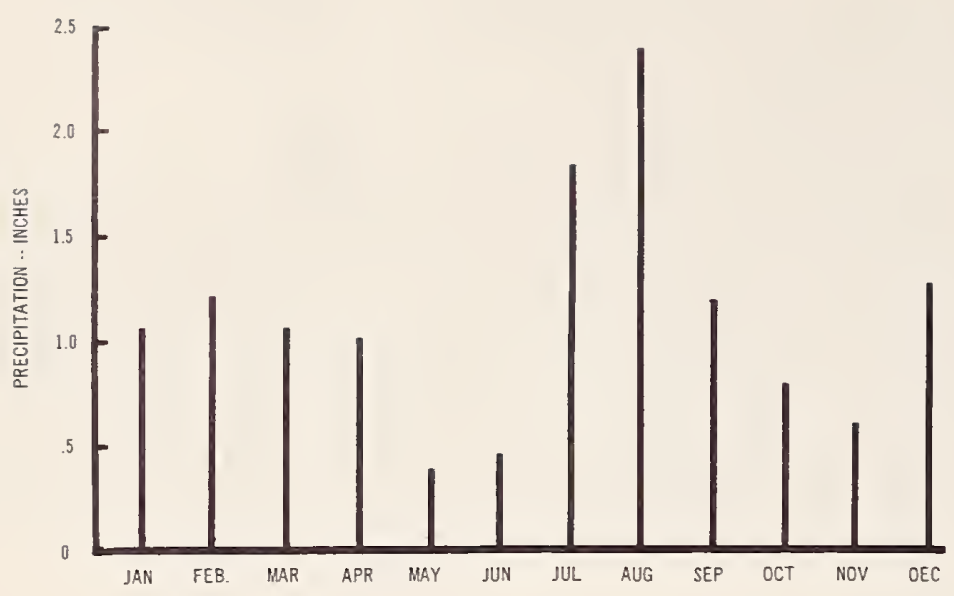

Figure 2.--Mean monthly precipitation at Ashfork, Arizona, from 1909 to.1953. (from Smith 1956.)

about September 15, is the time of best growth of blue grama, side-oats grama, spike muhly, and black dropseed. Black grama and galleta usually develop about 1 week earlier than blue grama. The summer growers utilize precipitation that falls from June through September. Periods of growth and maximum development of cool- and warm-season grasses are illustrated in figure 3 and table 1.

\section{Cool-Season Grasses}

Cool-season grasses maintained some overwinter greenness, but began active growth between March 10 and April 10 each year. These species are probably of northern origin (Bredemeier 1958, Hartley 1961) ${ }^{2}$ and probably have developed in an environment where temperature was the principal factor limiting growth. Some year-to-year growth variation within species was noted during March and early April; less difference was noted from April 10 to May 10. In the following paragraphs the increase in height of each species after April 10 is described.

\section{Mutton Bluegrass}

Overwinter green height was about 5 inches. Maximum growth of this species occurred between early April and mid-May. On the average, plants grew 6.5 inches from April 10 to

\footnotetext{
${ }^{2}$ Names and dates in parentheses refer to Literature Cited, page 7.
}

Table 1.--Time of maximum height and period of green growth of cool-and warm-season grasses

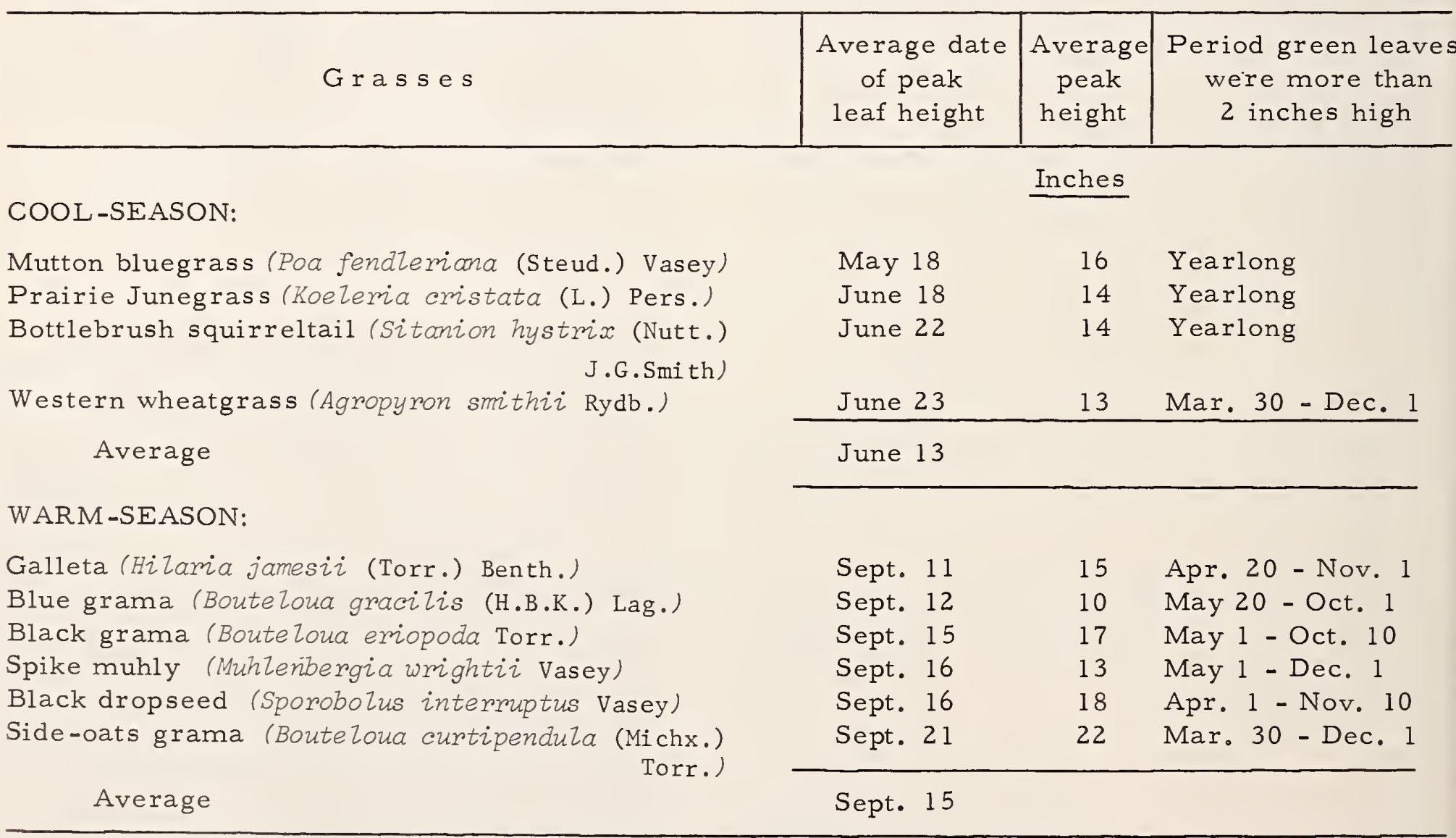




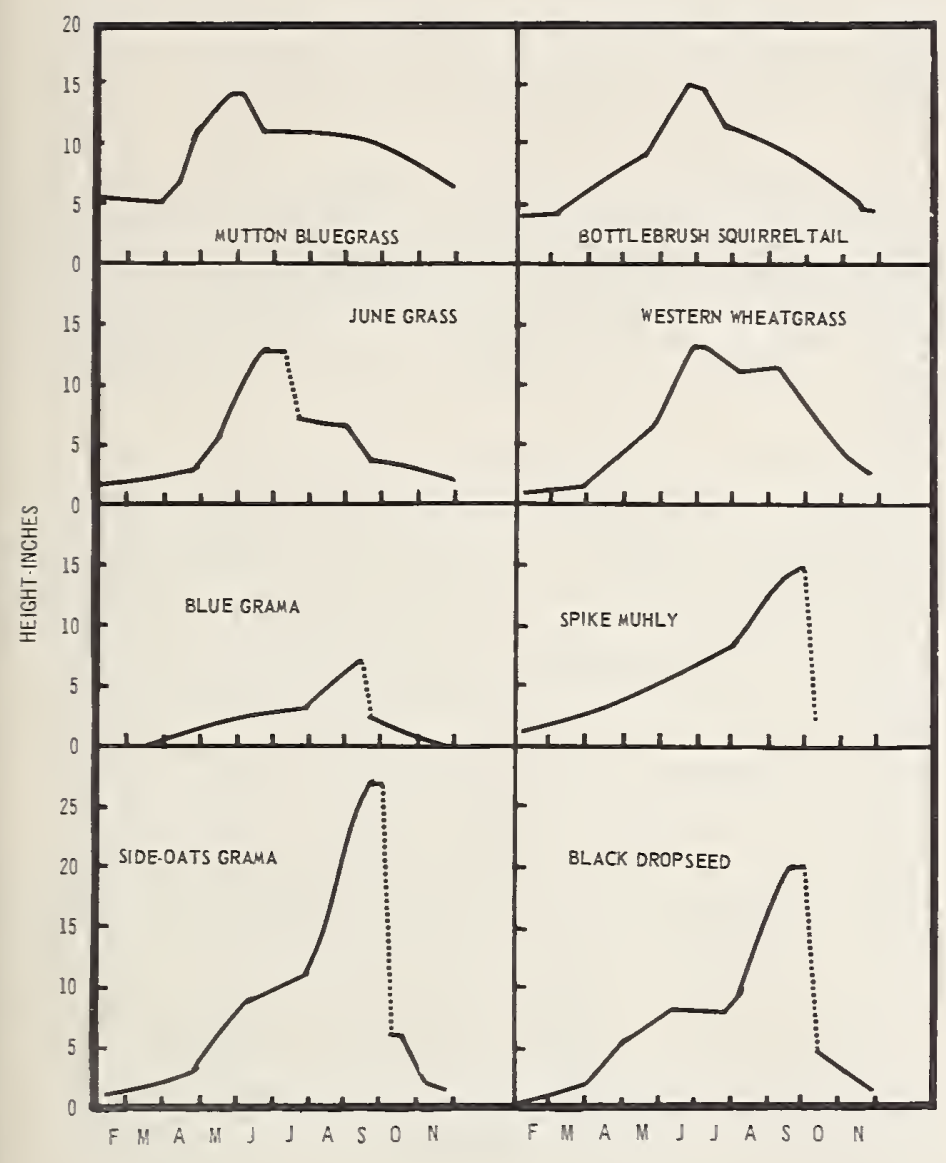

Figure 3.--Growth pattem of grasses 10 miles east of Ashfork, Amizona. Records are based on average maximum height of green leaves of 10 plants of each species measured for 3 to 4 years. Dashed lines indicate ropid dming of tops.

May 10 and another inch by May 20. Although growth of other cool-season grasses was not affected, relatively low temperatures during March $1958^{3}$ evidently retarded development of mutton bluegrass near Ashfork, Arizona, as shown below.

\begin{tabular}{|c|c|c|}
\hline Year & $\begin{array}{c}\text { Average March } \\
\text { temperature }\end{array}$ & $\begin{array}{c}\text { Average height } \\
\text { April } 10 \\
\end{array}$ \\
\hline & $(\mathrm{F})$ & (Inches) \\
\hline 357 & 43.2 & 8.2 \\
\hline 1958 & 36.6 & 5.9 \\
\hline$\perp 959$ & 44.2 & 8.8 \\
\hline 1960 & 46.3 & 8.0 \\
\hline
\end{tabular}

3emperature interpolated from U. S. Weather Bureau records for Williams and Ashfork, Arizona.
Bottlebrush Squirreltail

Overwinter green height was about 4 inches. This grass on the average grew 2 inches from April 10 to May 10, and another 4 inches by June 10. At some locations growth began in early March.

\section{Prairie Junegrass}

Overwinter green height was about 2 inches. Junegrass grew an average of 2 inches between April 10 and May 10. After May 10, growth was highly variable in different years.

\section{Western Wheatgrass}

Overwinter green height was about 1 inch. Spring growth of western wheatgrass began in late March. This grass grew an average of 2.5 inches from April 10 to May 10 and another 5 inches by June 10 .

Height growth of the cool-season grasses between April 10 and May 10 is reasonably predictable. Squirreltail, western wheatgrass, and Junegrass grew about $1 / 2$ inch a week during this period, and mutton bluegrass about 1-3/4 inches. By adding expected growth to existing growth, the time at which these species will reach a given height can be predicted. For example, if it were desired to begin grazing western wheatgrass when it is 4 inches high, and the height on April 10 was 2 inches, the predicted date of range readiness would be 4 weeks later, or May 8 .

\section{Warm-Season Grasses}

Leaves and stems of warm-season grasses generally became entirely brown for at least a short period during winter. The apparently dormant period for blue grama, black grama, and galleta is from late November to early March. Black grama, however, will often retain some greenness at the stem nodes over winter, even though its internodes appear completely cured. Side-oats grama, spike muhly, and black dropseed are apparently dormant for about a month during December and January. 
Height of warm-season grasses increased at a moderate rate in the spring; growth of most species then decreased and plant heights usually reached a plateau. Leaf height during this period of decreased growth is characteristic of the species:

\section{Species $\quad \frac{\text { Height during early summer }}{\text { (Inches) }}$}

Blue grama

$$
\begin{aligned}
2-3 \\
5-10 \\
2-4 \\
4-1 / 2-5-1 / 2 \\
7-8
\end{aligned}
$$

Side-oats grama

Black grama

Galleta

Black dropseed

The time at which the rate of growth began to diminish varied with elevation, apparently as a result of differences in temperature. For example, at the two low-elevation stations in this study (average elevation 5,900 feet), blue grama reached 2 inches in height on an average date of April 18. For the three highelevation plots (average elevation 6,400 feet), the 2-inch level was reached on May 11. The other warm-season grasses began to decline in growth rate at about the same time as blue grama.

The general rate of growth of the warmseason grasses from spring through mid-July is low, particularly after growth rate begins to decrease in May. There will be little apparent difference in the growth stage of these grasses for a period of several weeks during early summer, and there will probably be little difference in the effect on the plants whether grazing begins early in this period of semidormancy or late in the period.

In late July or early August, the warmseason grasses begin to develop flower stalks and increase rapidly in height (fig. 3). In dry years, however, few flower stalks develop and plant heights remain much the same as in June.

Timing of plant growth corresponds, in general, with timing of seasonal precipitation. Rains later than usual may delay growth, but there is good evidence that rains earlier than usual do not result in earlier growth of warmseason grasses. When blue grama seeds were collected from several locations, planted together, and irrigated, the period of growth of each collection was closely related to the summer rainfall pattern at the place of seed origin (table 2). This indicates that the period of growth is at least partly controlled by physiological mechanisms peculiar to particular grass strains. Strains that have developed under a particular rainfall regime have mechanisms suited to that regime. The grama grasses probably originated in the Southwest (Fults 1942), and local strains seem admirably suited to the normal Southwestern rainfall pattern.

Some strains of grasses, especially sideoats grama, flower during seasons when the days reach a certain length (Olmstead 1952);

Table 2.--Relationship between growth of blue grama strains and distribution of seasonal precipitation at seed source

\begin{tabular}{l|c|c|c}
\hline \multicolumn{2}{c|}{ Location } & \multicolumn{2}{c}{$\begin{array}{c}\text { Percentage of May-September } \\
\text { total by August 1 }\end{array}$} \\
\hline \multicolumn{1}{c|}{ Seed source } & Weather station & Growth & Precipitation $^{2}$ \\
\hline \multirow{2}{*}{$\begin{array}{l}\text { Great Plains } \\
\text { New Mexico-Texas }\end{array}$} & Scottsbluff, Nebraska & 71 & 70 \\
Arizona & Roswell, New Mexico & 52 & 52 \\
& Natural Bridge, Arizona & 40 & 45 \\
\hline
\end{tabular}

${ }^{1}$ Data from Riegel, 1940. "Great Plains" includes seed from each State from Oklahoma to Montana, but these were averaged here because all showed the same pattern.

2 Data from U. S. Dept. Agr., 1941. Weather stations were selected where 39- to 40-year records were available near the geographic midpoint of the region represented. 
the flowering period is generally such that there are usually favorable moisture conditions in the source locality of the strain. Lavin $^{4}$ found that Arizona strains of blue grama were definitely short-day plants, and Olmstead (1952) reported similar findings for side-oats grama. In other words, these plants will not flower until the days get short in late summer.

Data presented by McGinnies and Arnold (1939) show a definite periodicity of pounds of dry matter produced by grasses per pound of water consumed. The least efficient time of growth is, on the average, in May and June, and the most efficient time is in August and September.

The periodicity of flowering and water use demonstrates the principles of plant development outlined by Turesson (1931):

Climate strongly influences the distribution of the biotypes within a species, and one climatic region therefore harbors a distinct biotype group, genotypically different from the biotype group of another region.

This points out the need for using local strains for reseeding.

\section{AMOUNT OF GRASS GROWTH}

Since the most variable condition in the environment of plants is amount of available

${ }^{4}$ Lavin, Fred. Variations in the responses of different geographic strains of blue grama grass to photoperiod. 1953. (Unpublished Ph. D. dissertation on file at Univ. of Chicago.) soil moisture, one would expect that amount of grass growth is highly correlated with rainfall. Such is indeed the case, as has been shown several times. Some correlation coefficients between amount of rainfall and production are 0.94 in intermountain desert ranges (Hutchings and Stewart 1953), 0.93 for crested wheatgrass in New Mexico (Pingrey and Dortignac 1959), and 0.86 for a shortgrass range in Alberta (Smoliak 1956). Data reported by Nelson (1934) revealed a correlation coefficient of 0.96 between height growth of black grama and summer precipitation in southern New Mexico. Sneva and Hyder (1962) developed a formula for predicting production of range lands when the bulk of the precipitation falls in the winter, but most of the growth of the range plants occurs in the spring and early summer. Their equation is $Y=1.11 X-10.6$, where $Y$ is the percent of median forage production and $\mathrm{X}$ is the percent of median precipitation for the year. All that is needed to use this formula for a given area is to determine median precipitation and forage production for at least 1 year. The data of Pingrey and Dortignac (1959) apparently fall within the confidence limits of this equation, so it has been independently substantiated.

Relationships between height of cool-season grasses and precipitation in this study were not as clear as reported in the citations above. Heights of squirreltail and western wheatgrass were most closely related to JanuaryMarch precipitation, while heights of mutton bluegrass and Junegrass were related to February-March precipitation (table 3). Precipitation before January and after April was also compared to height growth of cool-season

Table 3.--Maximum height growth of cool-season grasses and winter precipitation 10 miles east of Ashfork, Arizona

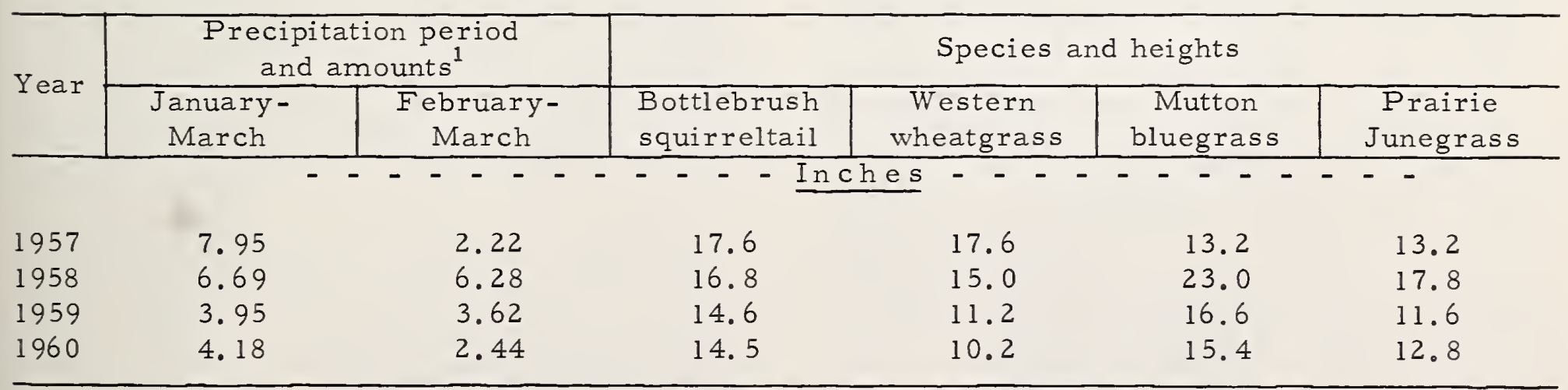

${ }^{1}$ Interpolated from U. S. Weather Bureau records at Williams and Ashfork, Arizona. 
grasses, but no relationship was apparent. That mutton bluegrass should have a later effective precipitation period than western wheatgrass and squirreltail seems paradoxical, since mutton bluegrass grows earlier than the other species. Arnold (1955) observed that mutton bluegrass made maximum growth when both precipitation and temperature were above normal for January, February, and March. His observation is generally supported by the data collected in this study.

In any event, it seems clear that precipitation before January and after April has little effect on height growth of the cool-season grasses. If the grazing season on these grasses is to be in the late spring and early summer, the amount of available feed is roughly predictable from the mid- to late-winter precipitation.

The growth of warm-season grasses is determined almost entirely from summer precipitation. Since these species are usually grazed during the time of effective precipitation, forage production cannot be predicted. The only help that the phenologic data collected in this study can be to a land manager in this regard is to provide guidelines to anticipate the probable growth a few weeks earlier than it actually occurs. For example, if a shortage of fall feed is apparent by late summer, a livestock operator may decide to advance the fall sale date to compensate for the expected feed shortage. Although summer precipitation-growth relationships could be developed, summer storms are usually very spotty and it would be unusual to have adequate rainfall data from which to predict growth on different parts of a range. For this reason, the approach used here is to predict plant height at the end of the season from growth made earlier in the season.

For blue grama, the earliest possible prediction date was August 15. Effects of dry periods up to August 1 can be offset by rainfall in early August, and, conversely, abundant rainfall in early summer may produce little growth if the late July-early August period is dry. By August 15, however, the growth pattern is fairly well set. Since maximum height of blue grama is attained about September 12, the land manager has about a 4-week lead in estimating total growth for the season. Maximum height at the end of the season will be about 1 inch plus $1-1 / 2$ times the height on August 15 (fig. 4). Although there is some variation from this relationship, it is clear that if there is less than 4 inches of height growth by August 15 there will be less than 7 inches by the end of the season. If there is over 4 inches of height growth by August 15, the final height growth for the season can be 7 to 20 inches.

\section{USE OF PHENOLOGIC DATA IN DESIGNING GRAZING SYSTEMS}

In designing a sound grazing system, one should consider development of the important species of the range, particularly those species that are present in less than desired amounts. If warm-season grasses are to be favored, they should be protected from grazing from about July 15 to October 15. On most pinyon-juniper ranges, however, the coolseason grasses are much more in need of protection. The period from about April 10 to July 1 is probably most critical for them. The first parts of spring and summer growth periods are important for growth, and the last parts are important for seed maturation and dissemination. None of the grasses included in this study appear to be especially sensitive to grazing from October 15 to April 10, but repeated use during the winter might result in damage to associated shrubs.

\section{SUMMARY}

With a good mixture of grasses, a pinyonjuniper range should supply ample green forage from April 1 to September 30, and some green feed all winter. Phenology and height growth of several important grasses in the pinyon-juniper type near Flagstaff, Arizona, were observed from 1957 to 1960. Cool-season grasses reached peak height between May 18 and June 23, and remained partly green all year. Warm-season grasses were green only during spring, summer, and fall, and reached peak heights between September 11 and September 21. 


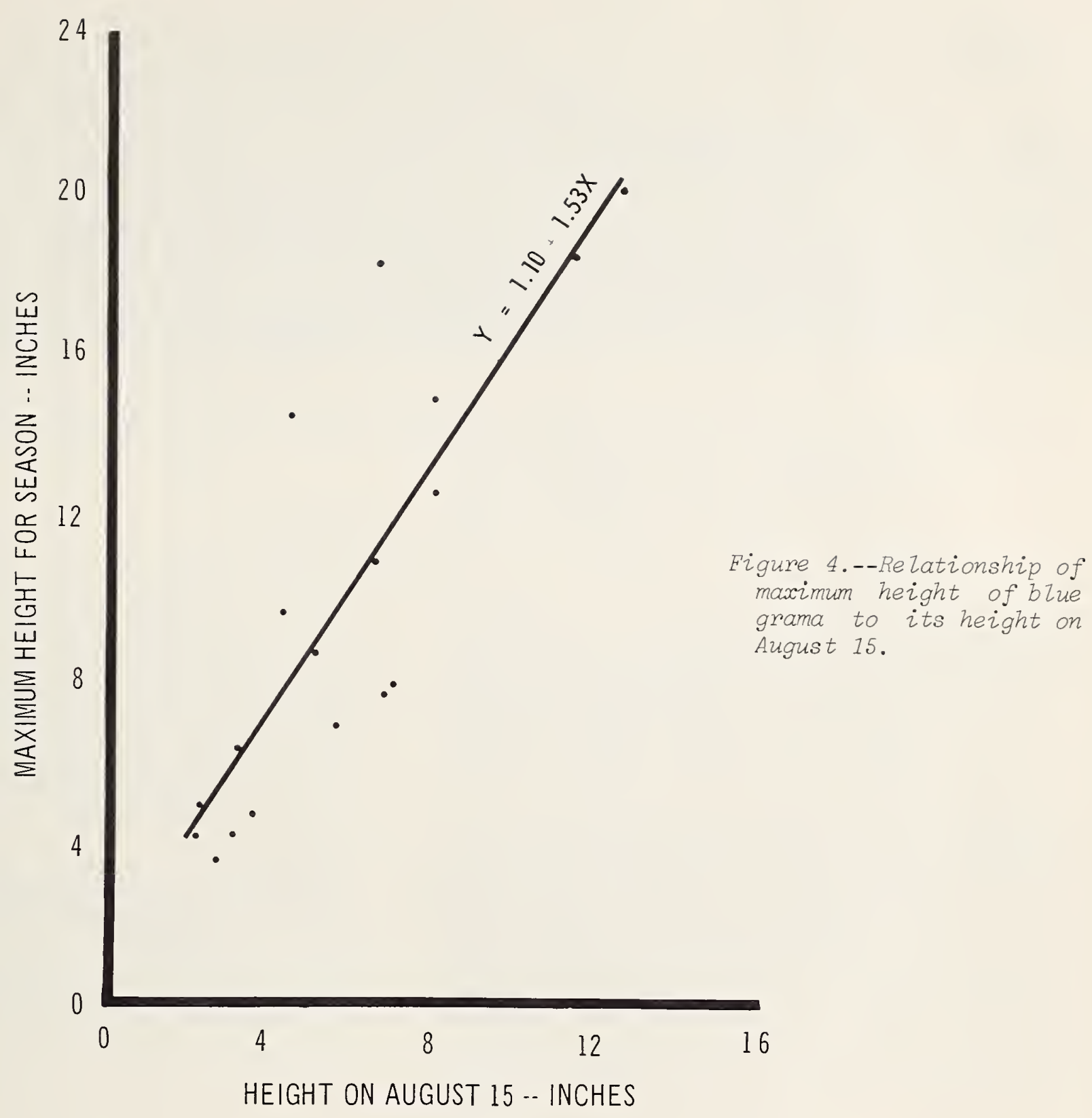

The amount of growth of each species is highly variable, and is determined mostly by the precipitation during or a month or two before the period of most active growth of each species. The dates at which certain growth periods occur, on the other hand, are orderly and fairly predictable. Cool-season grasses grow at a nearly uniform rate from April 10 to May 10. Maximum height of blue grama can be predicted 4 weeks before the maximum occurs.

Grazing systems should be designed to allow occasional rest for both cool- and warm-season grasses during their growth periods. Three periods should be recognized: "summer", July 10 to October 15; "winter",
October 15 to April 10; and "spring", April 10 to July 10. Because of differences in time of peak development of important grasses, forage production measurements should be taken in June for cool-season species and in September for warm-season species. For most of the pinyon-juniper type, cool-season grasses need more protection than warmseason grasses.

\section{LITERATURE CITED}

Arnold, Joseph F.

1955. Plant life-form classification and its use in evaluating range conditions and trend. Jour. Range Mangt. 8: 176-181, illus. 
Bredemeier, Lorenz $\mathrm{F}$.

1958. Measurement of time and rate of growth of range plants with applications in range management. Jour. Range Mangt. 11: 119-122, illus.

Fults, J. L.

1942. Somatic chromosome complements in Bouteloua. Amer. Jour. Bot. 29: 45-55.

Hartley, W.

1961. Studies on the origin, evolution, and distribution of the Gramineae. IV. The genus Poa L. Austral. Jour. Bot. 9: 152-161. (Biol. Ainst. 39: 12542.)

Hutchings, S. S., and Stewart, G.

1953. Increasing forage yields and sheep production on intermountain winter ranges. U.S. Dept. Agr. Cir. 925, $63 \mathrm{pp}$.

McGinnies, W. G., and Arnold, Joseph F.

1939. Relative water requirement of Arizona range plants. Ariz. Agr. Expt. Sta. Tech. Bul. 80: 167-246, illus.
Nelson, Enoch W.

1934. The influence of precipitation and grazing upon black grama grass range. U.S. Dept. Agr. Tech. Bul. 409, 32 pp., illus.

Olmstead, C. E.

1952. Photoperiodism in native range grasses. Sixth Internatl. Grassland Cong. Proc. 1952: 676-682.

Pingrey, H. B., and Dortignac, E. J.

1959. Economic evaluation of seeding crested wheatgrass on northern New Mexico rangeland. N. Mex. Agr. Expt. Sta. Bul. 433, 80 pp., illus.

Smoliak, S.

1956. Influence of climatic conditions on forage production of shortgrass rangeland. Jour, Range Mangt. 9: 89-91, illus.

Sneva, Forrest A。, and Hyder, D. N.

1962. Estimating herbage production on semiarid ranges in the Intermountain region. Jour. Range Mangt. 15: 88-93, illus.

Turesson, G.

1931. The selective effect of climate upon the plant species. Hereditas 14: 99-152. 